C/ORNL 98-0551

Carbon and Insulation Materials Technology Group Metals and Ceramics Division

CRADA Final Report

For CRADA Number ORNL-98-0551

\title{
Racing Radiators Utilizing ORNL's Graphite Foam
}

James Klett

Date Published October 10, 1998

Prepared for

Performance Research, LLC

Denver, NC

Prepared by the

OAK RIDGE NATIONAL LABORATORY

Oak Ridge, Tennessee 37831

Managed by

UT-BATTELLE, LLC.

for the

U. S. DEPARTMENT OF ENERGY

under contract DE-AC05-96OR22464 


\section{TABLE OF CONTENTS}

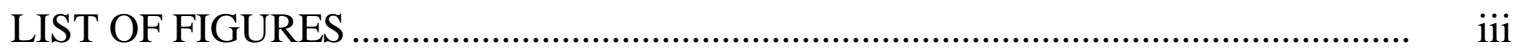

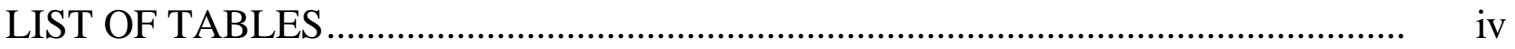

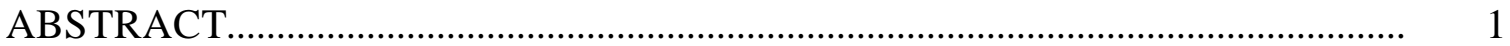

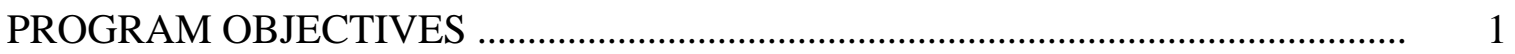

BENEFITS TO THE FUNDING DOE OFFICE'S MISSION ......................................

BACKGROUND

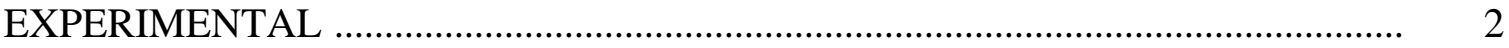

EXPERIMENTAL RESULTS

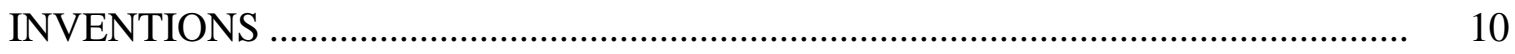

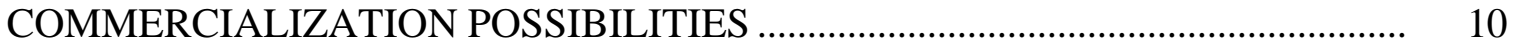

PLANS FOR FUTURE COLLABORATION ....................................................... 10

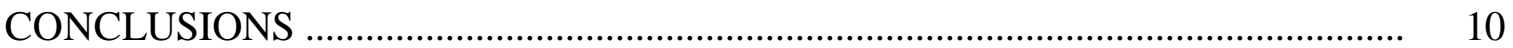


Figure

\section{LIST OF FIGURES}

13 -D view of one tube and tank array design.

Actual design included two tubes. .............................................................

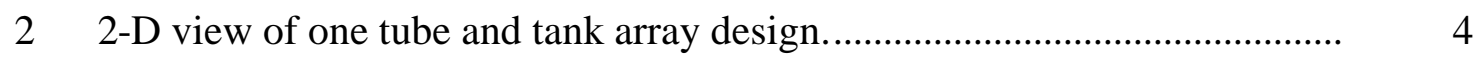

3 3-D view of tank array and ducting assembly. ..................................... 5

$4 \quad 3$-D view of air ducting assembly......................................................... 5

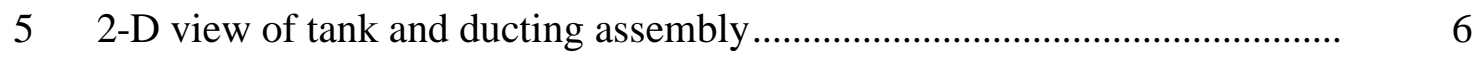

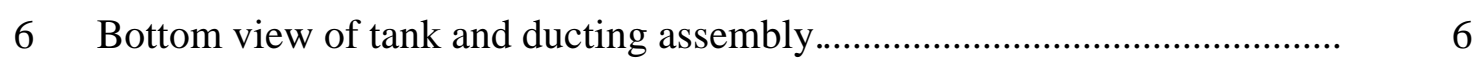

7 Plot of overall heat transfer coefficient versus air flow rates ......................... 7

8 Plot of overall heat transfer coefficient versus air flow rates for the modified brazed heat exchanger. 


\section{LIST OF TABLES}

Table

Page

I Experimental tests and results for the original heat exchanger....................

II Experimental tests and results for the modified brazed heat exchanger...... 8

III Experimental tests and results for the modified brazed heat

exchanger on a humid day.

10 


\begin{abstract}
The recent development of light-weight foams has led to novel light-weight, high strength carbon based materials and structures. These materials exhibit very high specific strengths and low thermal conductivities. Likewise, the novel development of very high thermal conductivity graphite foam will lead to novel "out-of-the-box" solutions for thermal management problems. With a thermal conductivity equivalent to aluminum 6061 and $1 / 5^{\text {th }}$ the weight, this material is an enabling technology for thermal management problems ranging from heat sinks to radiators and satellite panels to aircraft heat exchangers. In addition, the open porosity will lead to novel designs that incorporate porous media heat exchangers and phase change materials. For example, by utilizing the foam as a heat exchanger, heat transfer coefficients over two orders of magnitude greater than current metallic designs have been measured. To further demonstrate this phenomenon, a heat exchanger (radiator) for a passenger automobile has been developed that is significantly smaller in size, and testing has demonstrated feasibility to improve the automobiles aerodynamic efficiency and reduce weight.
\end{abstract}

\title{
PROGRAM OBJECTIVES
}

One objective of this CRADA was to gain an understanding of the behavior of ORNL's graphite foam as a potential heat exchange medium. A simple shell and tube heat exchanger with the foam as the core of the shell side of the exchanger was fabricated. Tests on the exchanger at various air flow rates and water flow rates to measure the overall heat transfer coefficient of the exchanger design utilizing the foam were performed.

\section{Benefits to the Funding DOE Office's Mission}

This was a 100\% Funds-in CRADA and, therefore, no DOE funds were spent. 


\section{BACKGROUND}

The purpose of this Cooperative Research and Development Agreement (CRADA) between Lockheed Martin Energy Research Corporation (Contractor), and Performance Research, Inc., (Participant), was to develop a fundamental understanding of the effects of heat transfer utilizing a carbon foam as a core material.

This research focused on the development of a highly thermally conductive carbon foam heat exchanger core with open porosity, and the measurement of the effective heat transfer coefficients. The carbon foam exhibits over two orders of magnitude greater useable surface area than current automotive radiators, thereby dramatically enhancing heat transfer from the engine fluid to the surrounding air. The results of this study will be utilized to design a lightweight, smaller radiator for automobile use. The smaller size of the radiator should help reduce drag and increase fuel efficiency.

A relatively simple technique for fabricating mesophase pitch-based carbon foams has been developed at by the Contractor. This technique produces graphitic foam with an open cell structure and an extremely high bulk thermal conductivity, $>100 \mathrm{~W} / \mathrm{m} \cdot \mathrm{K}$. The cell walls have a highly aligned graphitic structure, similar to high-performance carbon fibers, exhibiting interlayer spacing $\left(\mathrm{d}_{002}\right)$ of $0.336 \mathrm{~nm}$, coherence length $\left(\mathrm{L}_{\mathrm{a}, 100}\right)$ of 203 $\mathrm{nm}$, and a stacking height $\left(\mathrm{L}_{\mathrm{c}, 002}\right)$ of $442 \mathrm{~nm}$. Consequently, the struts of the foam exhibit a thermal conductivity between 700 and $1,200 \mathrm{~W} / \mathrm{m} \cdot \mathrm{K}$. Because of the low density, $\rho=0.5 \mathrm{~g} / \mathrm{cm}^{3}$, the specific thermal conductivity of the foam is over four times greater than that of copper. It has also been demonstrated that a foam core sandwich panel can be fabricated in-situ with integral high-thermal conductivity face-sheets, thus reducing thermal stresses and dramatically improving heat transfer efficiency. Moreover, the specific surface area of the open celled structure is over $4 \mathrm{~m}^{2} / \mathrm{g}$, resulting in a very large surface area to transfer heat to a working fluid (air).

The benefits of this technology are illustrated in this following example: a typical automobile radiator $0.1 \mathrm{~m}^{2}$ may have between $10-20 \mathrm{~m}^{2}$ of surface area. This area is directly related to the efficiency of the radiator to transfer the heat from the hot engine coolant to the surrounding air,, the higher the surface area, the better the heat transfer. A block of carbon foam 6-in. x 2-in. x 2-in. would exhibit over 10,000 $\mathrm{m}^{2}$ of surface area. This high surface area, theoretically, would allow a reduction of the size of the radiator by an order of magnitude, and still provide enough cooling effect to the engine.

\section{EXPERIMENTAL}

The objective of this CRADA was to gain an understanding of the behavior of ORNL's graphite foam as a potential heat exchange medium. A simple shell and tube heat exchanger with the foam as the core of the shell side of the exchanger was fabricated. Two aluminum tubes were brazed into slots machined into a foam block 4" x 4" x 1" thick using SuperBraze ${ }^{\circledR}$ low temperature solder. The heat exchanger was ducted and the tubes were manifolded to aluminum tanks on either side of the exchanger (see 
Figures 1-6). Tests were performed on the exchanger at various air flow rates and water flow rates to measure the overall heat transfer coefficient of the exchanger design utilizing the foam.

\section{EXPERIMENTAL RESULTS}

The Contractor fabricated foam appropriate for high air flow rates for inserting into the heat exchanger designed by the participant. The approximate density of the foam was $0.45 \mathrm{~g} / \mathrm{cm}^{3}$ and after graphitization the approximate thermal conductivity was 120 $\mathrm{W} / \mathrm{m} \cdot \mathrm{K}$. The contractor provided the samples to the participant for assembly into the heat exchanger designed and built by the participant (see Figures 1-6).

After the participant glued the foam into the heat exchanger, the contractor ran a series of tests to measure the overall heat transfer coefficient of the system. This consisted of attaching the heat exchanger to a hot water supply and an air supply. Hot water at approximately $80^{\circ} \mathrm{C}$ was passes through the exchanger at flow rates from 1 to 3 gallons per minute (gpm). Supply air was then passed through the foam side of the exchanger at flow rates between 6 and 20 standard cubic feet per minute (SCFM). Thermocouples were inserted into the inlet and outlet lines of both the water and air streams. The data from these experiments are shown in Table I.

From the energy balances, the heat lost (flux) of the water was calculated and is reported in Table I. From this, the overall heat transfer coefficient of the system was calculated for each run and is also reported in table I. These heat transfer coefficients are better presented as a function of air flow and water flow in Figure 7. As can be seen, the heat transfer coefficients are rather large, up to $3500 \mathrm{~W} / \mathrm{m}^{2} \cdot \mathrm{K}$. A typical automobile heat exchanger exhibits a overall heat transfer coefficient of about $250 \mathrm{~W} / \mathrm{m}^{2} \cdot \mathrm{K}$. This low value is typical of many other shell and tube heat exchangers (1). Clearly, the foam dramatically improved the heat transfer coefficients and should reduce the size and weight of a radiator for an automobile. 


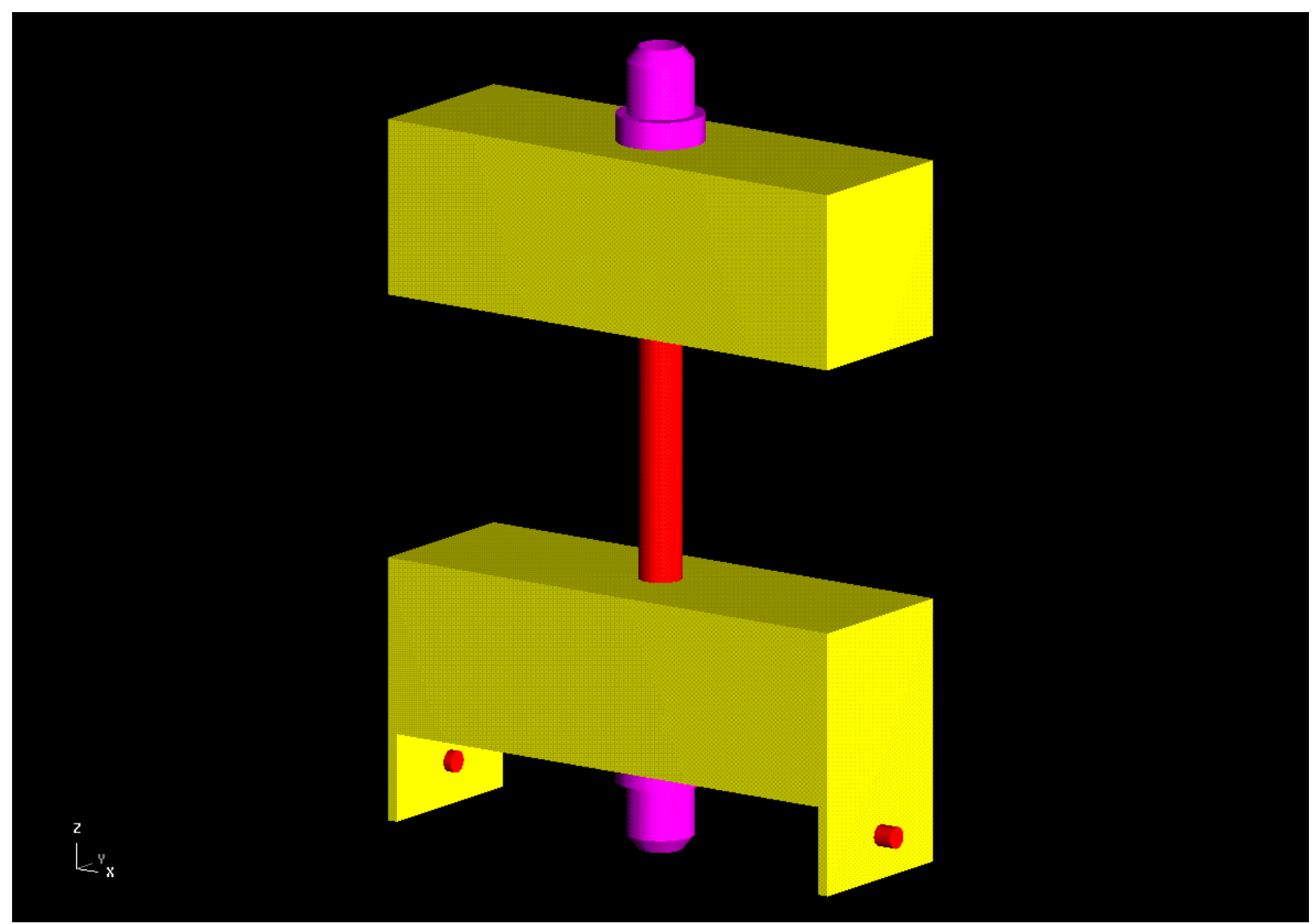

Figure 1. 3-D view of one tube and tank array design. Actual design included two tubes.

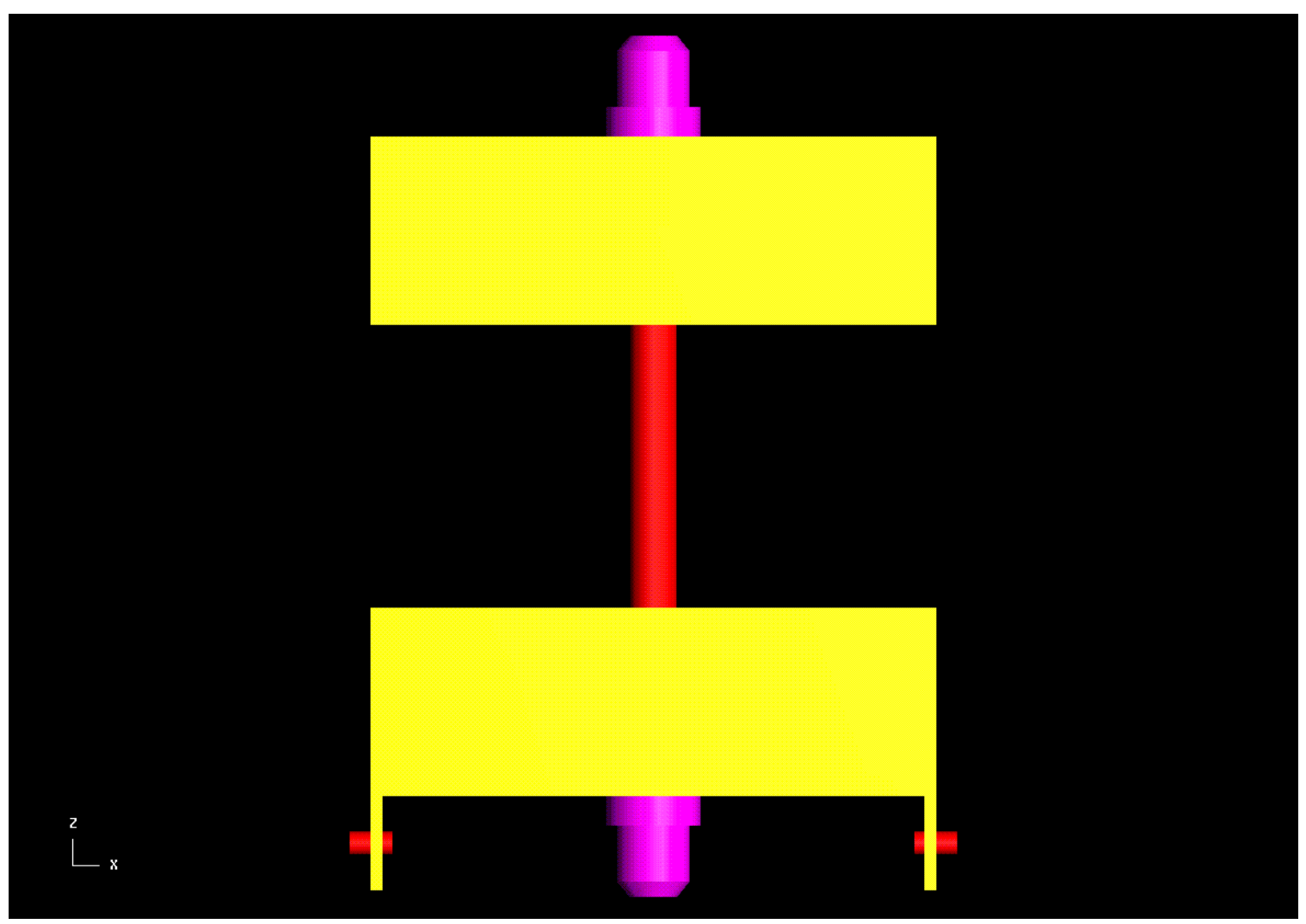

Figure 2. 2-D view of one tube and tank array design. 


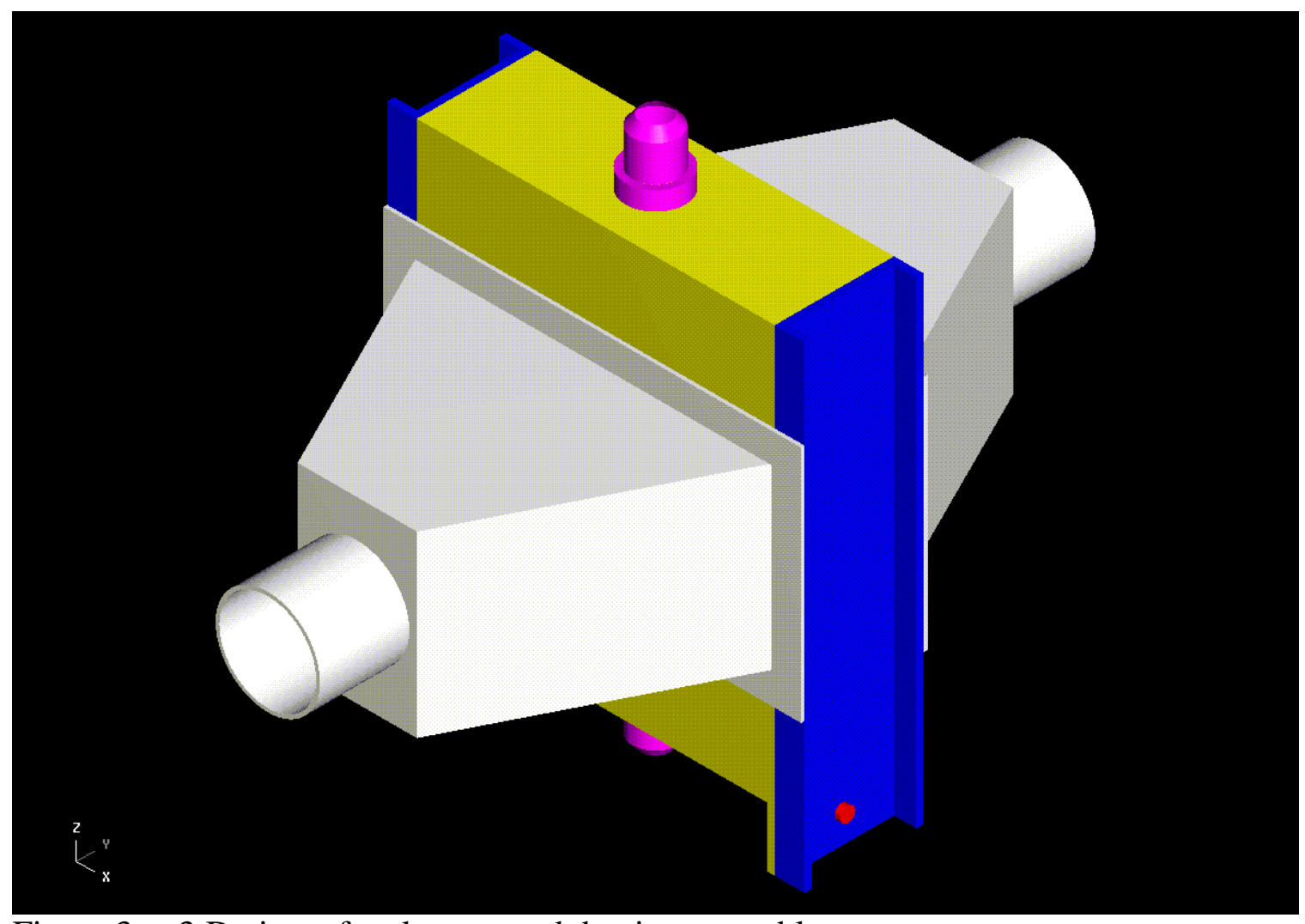

Figure 3. . 3-D view of tank array and ducting assembly.

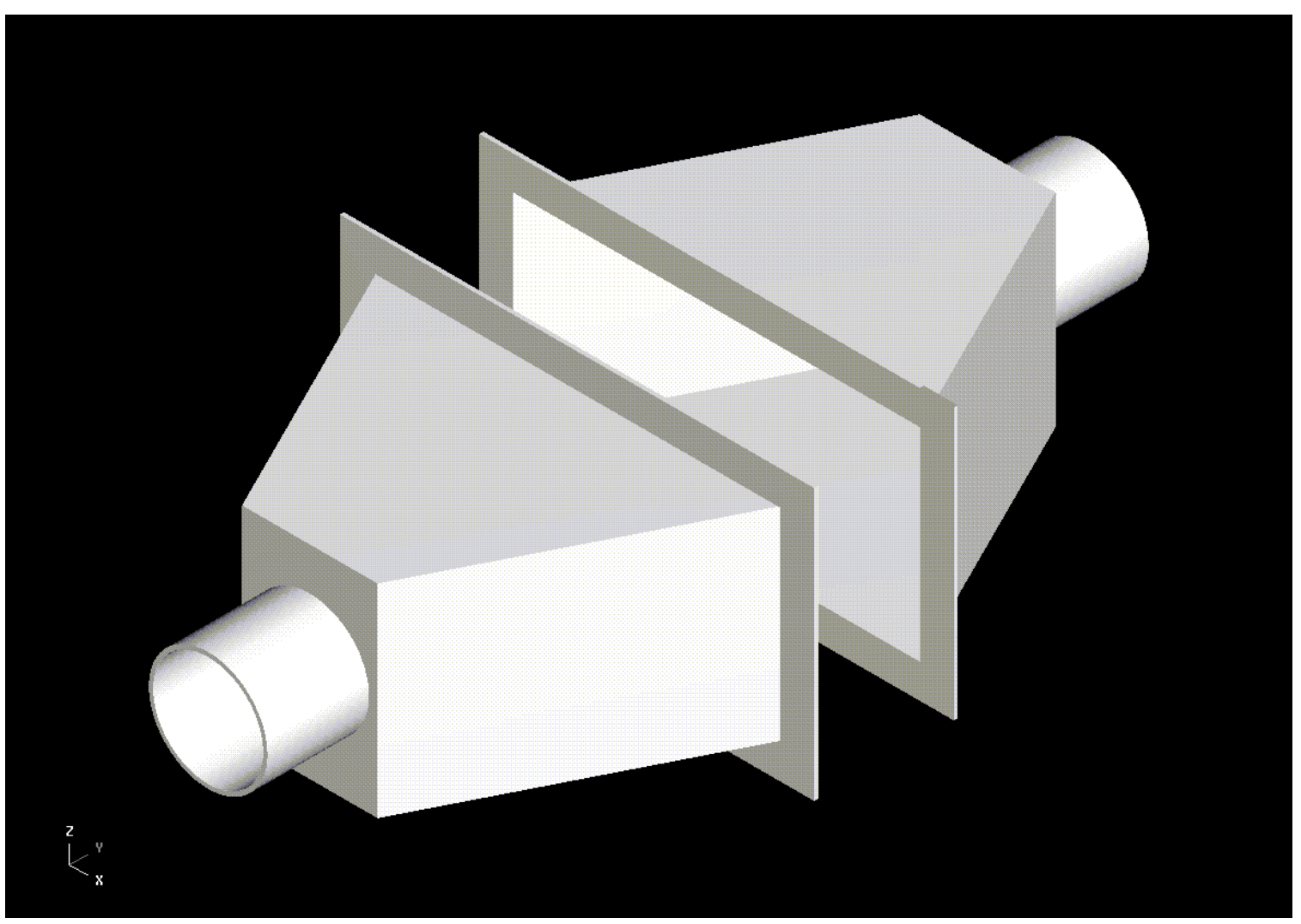

Figure 4. 3-D view of air ducting assembly. 


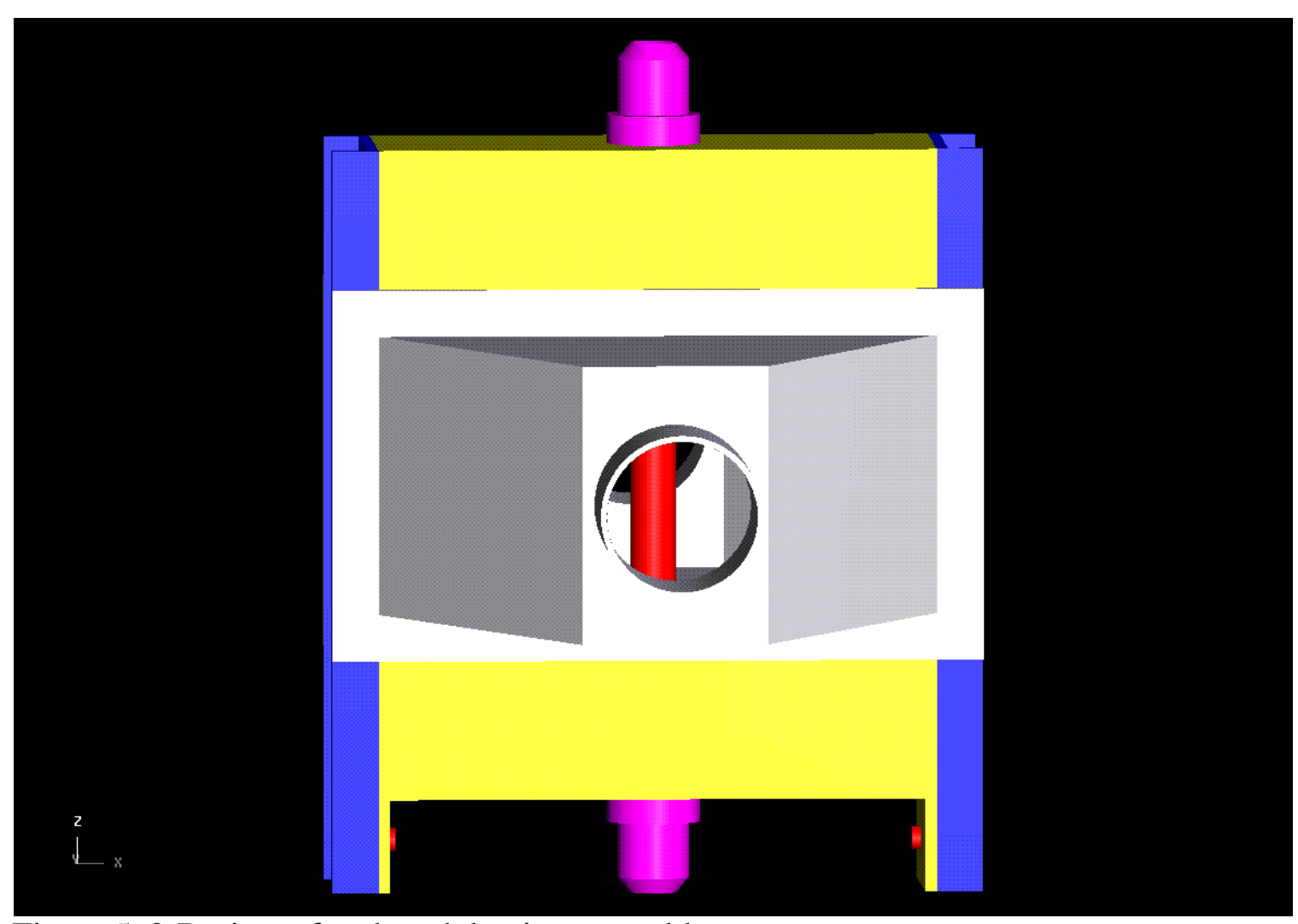

Figure 5. 2-D view of tank and ducting assembly.

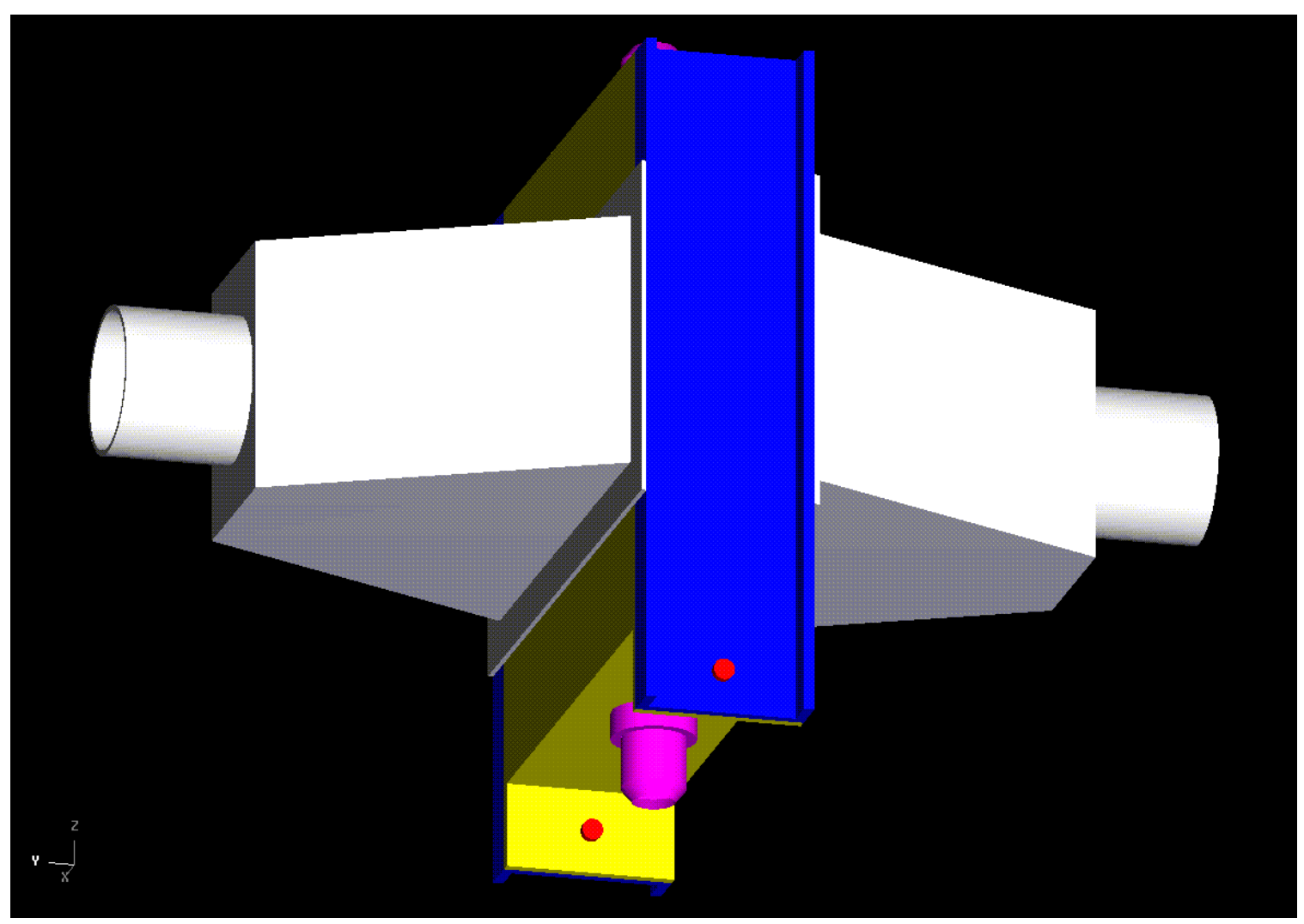

Figure 6. Bottom view of tank and ducting assembly. 
Table I. Experimental tests and results for the original heat exchanger.

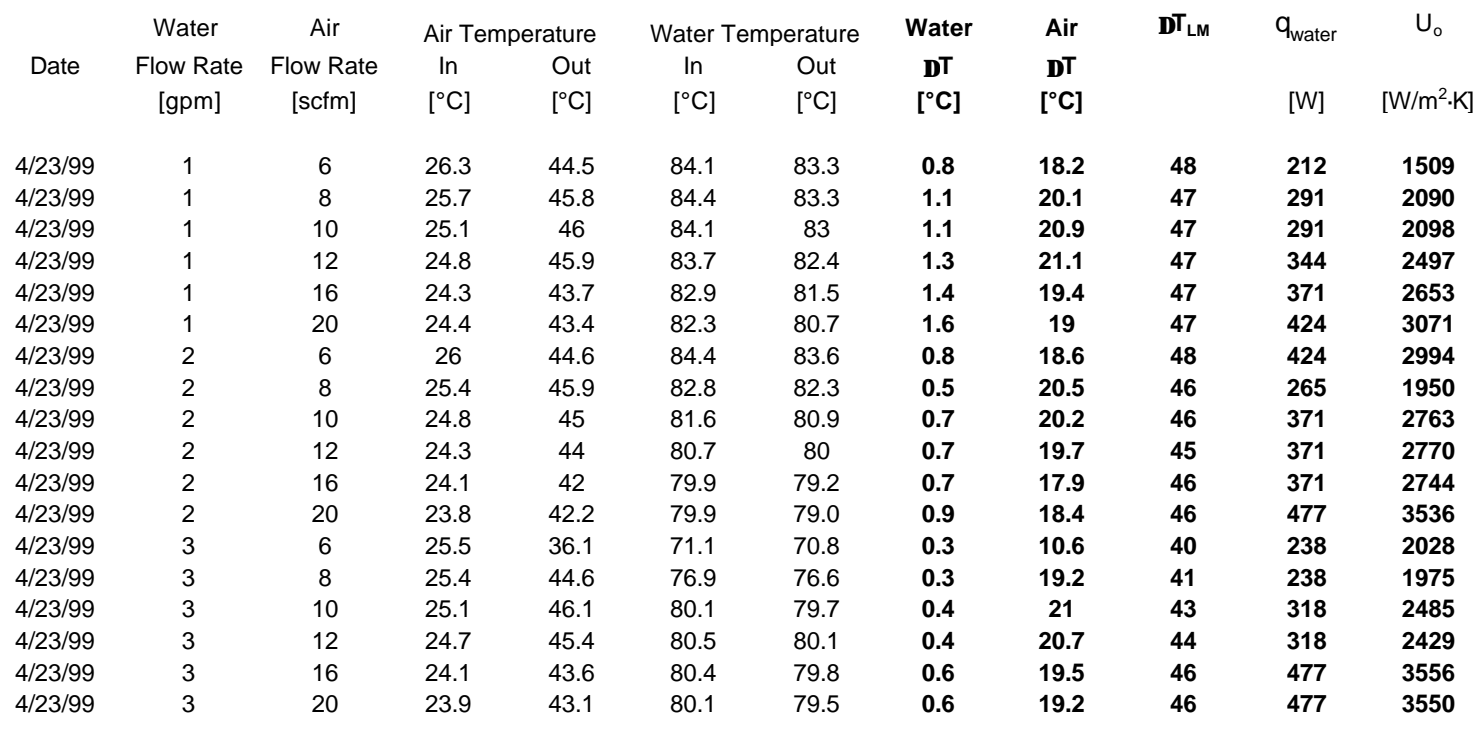

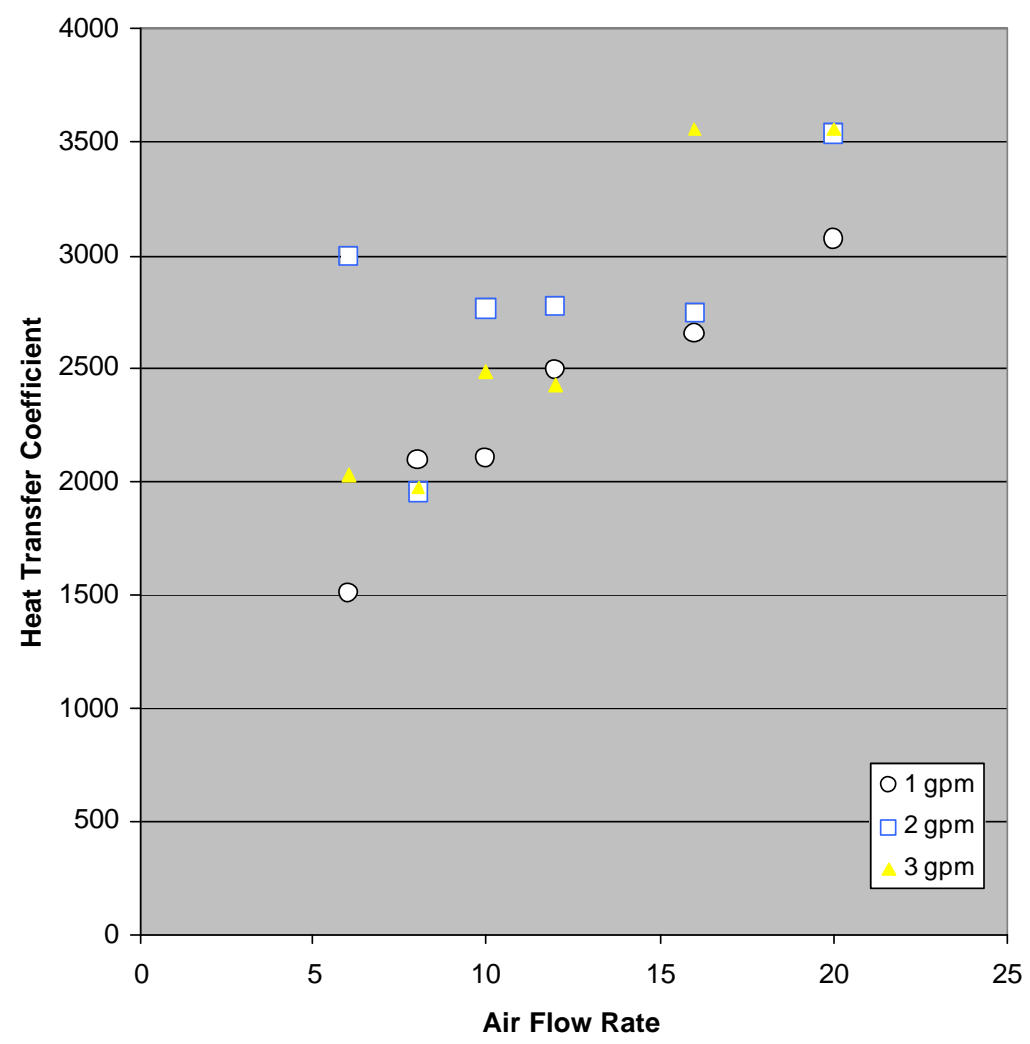

Figure 7. Plot of overall heat transfer coefficient versus air flow rates. 
There were two variables in this test that raised concern. The first was the fact that thermocouples are accurate to $1-2^{\circ} \mathrm{C}$ and the overall change in temperature of the waterside was no more than $2^{\circ} \mathrm{C}$, giving concerns to the accuracy of these numbers. It was suggested that the thermocouples be replaced by RTD temperature measurement devices which are accurate to $<0.1^{\circ} \mathrm{C}$. The second concern was the glue used to bond the foam to the tubes in the heat exchangers. It was shown in other research that glues could reduce the heat transfer from a metal surface to the foam by over fifty percent. Therefore, it was suggested that the foam be removed from the heat exchanger and replaced with foam that was brazed in place. It has been shown that the brazing technique will not reduce the heat transfer from the tubes to the foam by more than five percent. These were performed and the tests repeated. The data is presented in Table II and the overall heat transfer coefficients are reported in Figure 8. However, unlike before, these tests included airflow rates up to 70 SCFM.

Table II. Experimental tests and results for the modified brazed heat exchanger.

\begin{tabular}{|c|c|c|c|c|c|c|c|c|c|c|c|}
\hline \multirow[b]{2}{*}{ Date } & \multirow[b]{2}{*}{$\begin{array}{c}\text { Water Flow Rate } \\
\text { [gpm] }\end{array}$} & \multirow[b]{2}{*}{$\begin{array}{l}\text { Air Flow Rate } \\
\text { [scfm] }\end{array}$} & \multicolumn{2}{|c|}{ Air Temperature } & \multicolumn{2}{|c|}{ Water Temperature } & \multirow{2}{*}{$\begin{array}{c}\text { Water } \\
\qquad \mathbf{T} \\
{\left[{ }^{\circ} \mathrm{C}\right]}\end{array}$} & \multirow{2}{*}{$\begin{array}{c}\text { Air } \\
\Delta \mathbf{T} \\
{\left[{ }^{\circ} \mathbf{C}\right]}\end{array}$} & \multirow[t]{2}{*}{$\Delta \mathbf{T}_{\mathrm{LM}}$} & \multirow{2}{*}{$\begin{array}{l}\mathbf{q}_{\text {water }} \\
{[\mathrm{J} / \mathrm{min}]}\end{array}$} & \multirow{2}{*}{$\begin{array}{c}\mathrm{U}_{\mathrm{o}} \\
\left.\mathrm{[W} / \mathrm{m}^{2} \cdot \mathrm{K}\right]\end{array}$} \\
\hline & & & $\begin{array}{c}\text { In } \\
{\left[{ }^{\circ} \mathrm{C}\right]}\end{array}$ & $\begin{array}{l}\text { Out } \\
{\left[{ }^{\circ} \mathrm{C}\right]}\end{array}$ & $\begin{array}{c}\ln \\
{\left[{ }^{\circ} \mathrm{C}\right]}\end{array}$ & $\begin{array}{l}\text { Out } \\
{\left[{ }^{\circ} \mathrm{C}\right]}\end{array}$ & & & & & \\
\hline $6 / 1 / 99$ & 1 & 10 & 26.1 & 48 & 80.9 & 80.5 & 0.4 & 21.9 & 43 & 106 & 843 \\
\hline $6 / 1 / 99$ & 1 & 12 & 25.5 & 47.5 & 80.2 & 79.6 & 0.6 & 22 & 42 & 159 & 1272 \\
\hline $6 / 1 / 99$ & 1 & 16 & 24.8 & 46.8 & 79.6 & 78.9 & 0.7 & 22 & 42 & 185 & 1483 \\
\hline $6 / 1 / 99$ & 1 & 20 & 24.3 & 45.2 & 79.5 & 78.5 & 1 & 20.9 & 43 & 265 & 2075 \\
\hline $6 / 1 / 99$ & 1 & 40 & 24.5 & 41.8 & 75 & 73.4 & 1.6 & 17.3 & 40 & 424 & 3568 \\
\hline $6 / 1 / 99$ & 1 & 60 & 24.7 & 39.1 & 74.4 & 72.4 & 2 & 14.4 & 41 & 530 & 4391 \\
\hline $6 / 1 / 99$ & 1 & 70 & 24.8 & 37.8 & 74.5 & 72.3 & 2.2 & 13 & 42 & 582 & 4751 \\
\hline $6 / 1 / 99$ & 2 & 10 & 25.7 & 48.2 & 80 & 79.9 & 0.1 & 22.5 & 42 & 53 & 428 \\
\hline $6 / 1 / 99$ & 2 & 16 & 24.5 & 50.3 & 80.2 & 80 & 0.2 & 25.8 & 41 & 106 & 870 \\
\hline $6 / 1 / 99$ & 2 & 20 & 24.3 & 49.4 & 79.5 & 79.2 & 0.3 & 25.1 & 41 & 159 & 1309 \\
\hline $6 / 1 / 99$ & 2 & 40 & 24.4 & 43.1 & 75.3 & 74.7 & 0.6 & 18.7 & 40 & 318 & 2665 \\
\hline $6 / 1 / 99$ & 2 & 60 & 24 & 41.1 & 77.6 & 76.7 & 0.9 & 17.1 & 44 & 477 & 3679 \\
\hline $6 / 1 / 99$ & 2 & 70 & 24.6 & 39.3 & 75.5 & 74.6 & 0.9 & 14.7 & 43 & 477 & 3797 \\
\hline 6/7/99 & 1 & 20 & 24.7 & 50.7 & 80.9 & 79.5 & 1.4 & 26 & 41 & 371 & 3071 \\
\hline $6 / 7 / 99$ & 1 & 30 & 24.2 & 47.3 & 80.2 & 78.4 & 1.8 & 23.1 & 42 & 477 & 3823 \\
\hline $6 / 7 / 99$ & 1 & 40 & 24.4 & 44.5 & 79.3 & 77.1 & 2.2 & 20.1 & 43 & 582 & 4623 \\
\hline $6 / 7 / 99$ & 1 & 50 & 24.3 & 42.8 & 78.9 & 76.5 & 2.4 & 18.5 & 43 & 635 & 4982 \\
\hline 6/7/99 & 1 & 60 & 24.0 & 42.4 & 82.6 & 80.1 & 2.5 & 18.4 & 47 & 662 & 4744 \\
\hline $6 / 7 / 99$ & 1 & 70 & 24.8 & 40.6 & 80.2 & 77.5 & 2.7 & 15.8 & 46 & 715 & 5332 \\
\hline $6 / 7 / 99$ & 2 & 20 & 25.4 & 51.3 & 79.5 & 78.6 & 0.9 & 25.9 & 39 & 477 & 4130 \\
\hline $6 / 7 / 99$ & 2 & 30 & 24.6 & 48.8 & 78.4 & 77.4 & 1 & 24.2 & 40 & 530 & 4509 \\
\hline $6 / 7 / 99$ & 2 & 40 & 24.8 & 46.9 & 76.7 & 75.6 & 1.1 & 22.1 & 39 & 582 & 5051 \\
\hline $6 / 7 / 99$ & 2 & 50 & 24.8 & 44.6 & 76.4 & 75.3 & 1.1 & 19.8 & 40 & 582 & 4914 \\
\hline $6 / 7 / 99$ & 2 & 60 & 25.0 & 42.8 & 76.8 & 75.5 & 1.3 & 17.8 & 42 & 688 & 5630 \\
\hline $6 / 7 / 99$ & 2 & 70 & 25.1 & 41.6 & 77.8 & 76.4 & 1.4 & 16.5 & 43 & 741 & 5837 \\
\hline
\end{tabular}




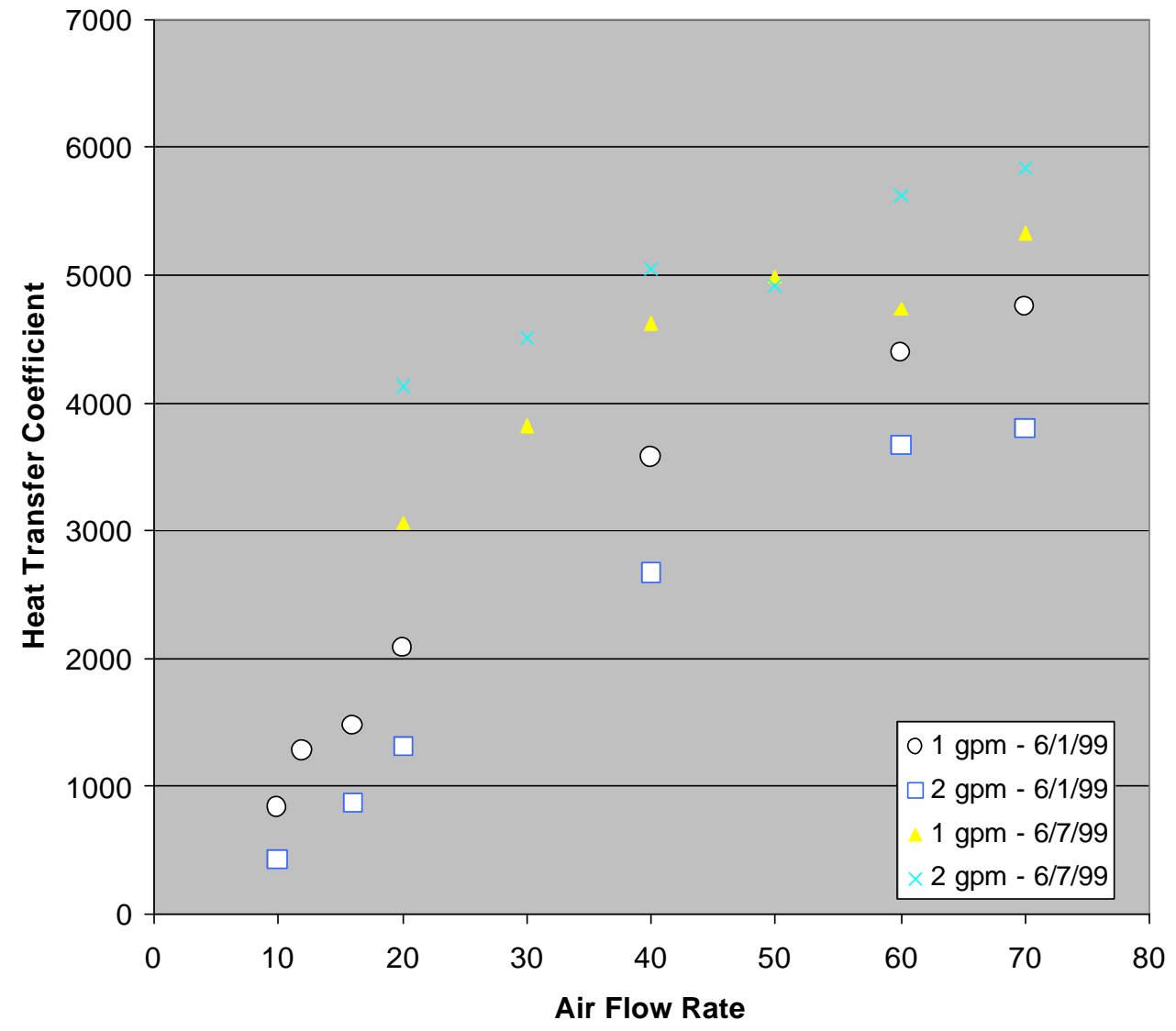

Figure 8. Plot of overall heat transfer coefficient versus airflow rates for the modified brazed heat exchanger.

As can be seen from Table II and Figure 8, the heat transfer coefficient at 20 SCFM did seem to increase in the brazed foam compared to the original results. However, the results were significantly different on different days. This is most likely due to the differences in humidity. The humidity in the air can dramatically affect the heat capacity of the air and, therefore, affect the amount of heat removed. Since the plant air was not dried prior to use, this is the most probable source of the variability in these data.

To test this theory, the heat exchanger was tested on a day that was reported to have over 90\% humidity. The results are listed in Table III. The calculated heat transfer coefficients are dramatically higher, over $10,000 \mathrm{~W} / \mathrm{m}^{2} \cdot \mathrm{K}$. Compared to a typical shell and tube heat exchanger this value of $10,000 \mathrm{~W} / \mathrm{m}^{2} \cdot \mathrm{K}$ is a remarkable improvement. The overall heat transfer coefficient also increased with increasing air and water flow rates. Further improvements in heat transfer coefficient may be anticipated for larger, more relevant, systems where the water flow rate can be up to $15 \mathrm{gpm}$ and the air flow rate may be as great as $500 \mathrm{SCFM}$ 
Table III. Experimental tests and results for the modified brazed heat exchanger on a humid day.

\begin{tabular}{|c|c|c|c|c|c|c|c|c|c|c|}
\hline \multirow{2}{*}{$\begin{array}{c}\text { Water } \\
\text { Flow Rate } \\
\text { [gpm] }\end{array}$} & \multirow{2}{*}{$\begin{array}{c}\text { Air } \\
\text { Flow Rate } \\
\text { [scfm] }\end{array}$} & \multicolumn{2}{|c|}{ Air Temperature } & \multicolumn{2}{|c|}{ Water Temperature } & \multirow{2}{*}{$\begin{array}{c}\text { Water } \\
{ }^{\Delta T} \\
{\left[{ }^{\circ} \mathbf{C}\right]}\end{array}$} & \multirow{2}{*}{$\begin{array}{c}\text { Air } \\
{ }_{\Delta T} \mathrm{~T} \\
{\left[{ }^{\circ} \mathrm{C}\right]}\end{array}$} & \multirow[t]{2}{*}{$\Delta \mathbf{T}_{\mathrm{LM}}$} & \multirow{2}{*}{$\begin{array}{c}\text { q water } \\
{[\mathrm{W}]}\end{array}$} & \multirow{2}{*}{$\begin{array}{c}\mathrm{U}_{0} \\
{\left[\mathrm{~W} / \mathrm{m}^{2} \cdot \mathrm{K}\right]}\end{array}$} \\
\hline & & $\begin{array}{c}\text { In } \\
{\left[{ }^{\circ} \mathrm{C}\right]}\end{array}$ & $\begin{array}{l}\text { Out } \\
{\left[{ }^{\circ} \mathrm{C}\right]}\end{array}$ & $\begin{array}{c}\text { In } \\
{\left[{ }^{\circ} \mathrm{C}\right]}\end{array}$ & $\begin{array}{l}\text { Out } \\
{\left[{ }^{\circ} \mathrm{C}\right]}\end{array}$ & & & & & \\
\hline 0.75 & 20 & 24.3 & 48.6 & 79.4 & 75.8 & 3.6 & 24.3 & 40 & 715 & 6142 \\
\hline 1 & 20 & 24.3 & 49.3 & 79.7 & 76.7 & 3 & 25 & 40 & 794 & 6782 \\
\hline 1 & 20 & 24.6 & 48.1 & 78.9 & 75.7 & 3.2 & 23.5 & 39 & 847 & 7292 \\
\hline 2 & 20 & 24.5 & 50.3 & 79.9 & 77.4 & 2.5 & 25.8 & 40 & 1324 & 11359 \\
\hline
\end{tabular}

\section{INVENTIONS}

None were made.

\section{COMMERCIALIZATION POSSIBILITES}

An option on a license for the use of foam in motor sports applications as a primary and secondary heat exchanger was taken by Performance Research, LLC.

\section{PLANS FOR FUTURE COLLABORATION}

The parties plan to collaborate in future work through consulting arrangements.

\section{CONCLUSIONS}

Carbon foam core radiator heat transfer coefficients more than two orders of magnitude greater than traditional radiators were measured. The remarkable thermal properties of the foam described here (a bulk thermal conductivity as high as $150 \mathrm{~W} / \mathrm{m} \cdot \mathrm{K}$ and a specific conductivity up to 6 times greater than that of copper) potentially make the foam an enabling material for many technologies. These unique thermal properties, combined with the continuous graphitic open-celled network of foam (unlike carbon fiber reinforced composites), should lead to novel and interesting methods of thermal management.

Although the data and discussion presented in this paper illustrate the potential of this material to be an enabling technology for many applications, further work is needed. A design for an automobile radiator which is dramatically smaller than current systems has been developed. However, when the full potential of this material is utilized, a radically different design that does not resemble the normal concept of a radiator may result. The full potential of the foam material will not be realized when used simply as a replacement for existing thermal management materials, but rather when it is utilized in out-of-the-box designs. 


\section{DISTRIBUTION}

1. Bret Conway, Performance Research, 3684 Delling Downs Road, Denver, NC 28037.

2. J. W. Klett, Bldg. 4508, MS 6087.

3. T.D. Burchell, Bldg. 4508, MS 6088.

4. R. A. Bradley, Bldg. 4500N, MS 6161.

5. C. A. Valentine, 111 UNV, MS 6499.

6. D. R. Hamrin, Bldg. 4500N, MS 6285.

7. P. A. Carpenter, Bldg. 4500N, MS 6269.

8. D. P. Stinton, Bldg. 4515, MS 6063.

9. D. R. Johnson, Bldg. 4515, MS 6066.

10. P. S. Sklad, Bldg 4515, MS 6065.

11. DOE-WFO, MS G209.

12-13. Office of Science and Technology Information, Box 62, Oak Ridge, TN, 37831. 